\title{
Educational Qualification: A Major Factor That Determines Understanding of Media Content among Rural Masses
}

\author{
S Maxwell Lyngdoh, Martin Luther Christian University, India \\ Samuel Wilson Meshack, Hindustan Bible Institute, India
}

\begin{abstract}
Objective: To determine how educational qualification acts as a major factor for the rural masses in understanding and to be able to comprehend the messages and information provided by the Government through various media vehicles while seeking assistances for government schemes and grants to alleviate poverty. Methodology: A descriptive, cross sectional study design, collecting relevant quantitative and qualitative data from the respondents was conducted. A data on retrospective histories and experiences of poverty was captured to link how being literate is important to understand information through media vehicles. Setting: Rural communities of Khasi tribal people in three Blocks of East Khasi Hills District, Meghalaya ie,. Mawsynram, Pynursla and Mawryngkneng. Results: Poverty in communication is one of the root causes of economic poverty. One of the major causes of poverty is people not being aware of government schemes and grants. People do not watch, listen or read certain exhibits of the media because they do not understand the language. Conclusion: The rural masses failed to understand that illiteracy is actually a barrier between them and government's information. They are not able to comprehend the content of such messages nor are they able to follow up to .attain these facilities.
\end{abstract}

Keywords: educational qualifications, understanding media content, grants 


\section{Introduction}

While Shillong, which is the capital city of Meghalaya is considered to be an educational hub, the National Institute of Rural Development (NIRD), reported that the literacy rate of Meghalaya is the second lowest among the North Eastern States with 62.60\% (Summary Report, NIRD-NERC, n.d.) as compared to Mizoram with the third highest literacy rate of $88.80 \%$ in the country.

During 2004-05, as many as 7.90 million persons live below poverty line in the North Eastern Region as against 280 million in India (HDR, 2003, UNDP) and the report shows that high poverty ratios are also found in Meghalaya with 18.5\%. Rural poverty which has a high concentration among the self-employment in agriculture is reported at $63.6 \%$ in the State. However, when it comes to reduction of poverty during the years 1973-74 and 1999-2000, it was highest in both Meghalaya and Mizoram (30.85\%) as against all India level of 28.78\%.

A high percentage of the poor people in the villages who concentrates on self-employed through agriculture exhibit poor performance in agriculture and adding to this list is Meghalaya which is listed in six out of the eight North Eastern States who reports to have contributed to agriculture very minutely. There are numerous reasons for poor performance of agriculture in the North Eastern Region and one of the prominent reasons is the serious problem of inaccessibility which leaves the people unconnected with many schemes and grants provided by the Government (Summary Report, NIRD-NERC, n.d.).

If one has to study the Eleventh Five Year Plan, the Plan targets reduction of poverty by $10 \%$ and to generate employment opportunities and also to ensure supplying of electricity connection to all the rural interiors. A foremost push of the Plan is on social sector which includes agriculture and rural development with $74.67 \%$ of allocation made from $55.22 \%$ in the Tenth Plan. The pertinent points stressed in the Plan are electricity supply, agriculture and rural development.

In trying to define poverty, one can say that "Poverty implies a state of privation and lack of necessities and it denotes serious lack of the means for proper existence: living in a state of extreme poverty" (dictionary.com, 2016). One definition that talks about poverty in relation to education is that which was given by the World Bank Organization (Economic and Social Inclusion Corporation, 2008-2009), which describes poverty as hunger, lack of shelter, a state 
of being sick and not being able to see a doctor, it also describes poverty as a state of not having access to school and not knowing how to read and write.

While we may all agree that education is the only means that can lead the road to a betterment of any community and the nation at large, we may also agree that education in rural India still needs a serious check-up with children failing to receive basic quality education and most importantly it may be reminded that rural education constitutes almost $90 \%$ of the schools being located in rural areas (Foradian, 2013). As correctly pointed out by Kaur (2013), who referred to the findings of ASER (Annual Status of Education Report), where students who have passed their fifth grade are not able to understand and read text books of lower classes and are not able to solve simple mathematical problems which clearly shows the quality of education that is being maintained in our villages and rural interiors. Kaur reiterates that majority of people living in rural interiors have understood the requirement of education as a step to get rid of poverty, but due to lack of money, are unable to provide their children good education.

The Right to Education Act which was passed in India on April 1, 2010 clearly mentions that education for all the children between the age group of six and fourteen years of age will be free of cost and will apply to all elementary education. This means to suggest that education is now a fundamental right of every child between the ages of 6 and 14 even in the rural areas. According to government estimates, there are nearly 220 million children in the mentioned age group out of which 9.2 million have never been to school (Kurukshetra, 2011). Critically analyzing these figures is something that may be operationalized only in paper while the actual reality is something else. Hazra (2011) has very well expressed in accordance with the $11^{\text {th }}$ Five Year Plan that access to education is the need of the hour to be able to create opportunities of employment for the rural people that will in turn enhance economic growth. This statement clearly shows the link that education promotes economic growth which is why education has been a major thrust in this country since independence; but like the above statements suggest, ensuring quality education in rural India has always been one of the biggest challenges for the Government of any State.

Print media is the industry that is associated with the printing and dissemination of news through newspapers while electronic media on the other hand is the use of electronic 
technology in broadcasting (Radio) and or telecasting (Television) news to the masses (Business Dictionary, 2016). In both the types, the dissemination of news is primarily for the masses both in the urban and rural areas. In such segregation, the newspapers available to the people are the Khasi (local dialect) Dailies and the English Dailies and likewise, the dialects used in Radio and Television are available in both Khasi and in English.

Sambhaji (2015) has rightly opined in his article when he mentioned that that media touches the remotest village and connects the whole universe together. One cannot deny the significant role played by the media in this country in bringing in development, even more after the attainment of independence. This is perhaps one reason why Haloi (2015) clearly stated that 'the role of media in the process of rural development has been recognized ever since the beginning of planned development in India'. This implies that media's efficiency in communicating with the rural masses has been identified long ago in India. Haloi further went on to stress that the sociologist thinkers have added media into the list of basic social needs because of the diverse roles that media plays in remote interiors.

Mathur (2006) on the other hand echoes literature that many rural villages in India still remains media starve. While this seem to be a technical lapsed on behalf of the Government, we need to also keep in mind that there is high level of illiteracy with low quality of education among the rural masses (Ochen \& Nwankwo, 2012). Adding to this, one need to understand that information often passes through quite a few channels before it reaches the receiver, but when the message is passed on, it is not passed on in exactly the same manner in which it was intended to be delivered as not all communication is deliberate. In other words, the message that the rural masses receive may not always match with the one that the source intends to pass (Food and Agriculture Organization of the United Nations, n.d). The percentage of this mismatch is very high in particular with all the village masses that are illiterate and are not able to understand the content provided to them through the media.

\section{Method}

This research carried out a descriptive, cross sectional study design, collecting relevant quantitative and qualitative data, as well as capturing some retrospective histories and experiences of exposure from media vehicles that the rural masses from the selected villages 
and respondents had in the past and even during the present time. Suitable sampling methods and appropriate data gathering tools were then developed.

Assuming that about $40 \%$ of the households will have access to any type of media, with a confidence interval of $95 \%$ and a relative precision of $10 \%$, therefore a minimum of 808 households needs to be studied. In order to capture the prevailing media exposure of the villagers and media reach to the population, it was proposed to take a multi stage sampling design.

At the first stage, Meghalaya State was chosen for the study in which East Khasi Hills District was selected out of the 11 districts available. In the second stage, three Blocks were selected based on the geographical representation out of the total number of eight blocks. In these blocks, villages were chosen based on the distance, which is very far off, not so far and near to the block head quarters. This was purposively done to cover all the villages at various distances, which are spread across these blocks. In the final stage, systematic random samplings of the households were taken. One out of every ten households was taken as respondents covering all the households in the villages systematically. This sampling was expected to yield a minimum sample size of how we arrive with a sample size of 808 households.

From each of the Blocks, the villages were segregated based on the distance from the blocks. It was proposed to select a random sample, taking into account the possible variations depending on the kind of exposure and accessibility they get through media. For a distance between 1-20 Kms, Mawryngkneng has 15 Villages, for a distance between 20-50 Kms, there are 25 Villages, for a distance between $50-80 \mathrm{Kms}$, there are 18 Villages and for a distance of 80-110 Kms, there are 6 Villages.

Pynursla on the other hand has 59 Villages for a distance between 1-20 Kms and 71 Villages for a distance between 20-50 Kms. On a similar sample size, Mawsynram has 42 Villages for a distance between 1-20 Kms, 63 Villages for a distance between 20-50 Kms and 53 Villages for a distance between $50-80 \mathrm{Kms}$. This is shown in Table I (A) 
Table I (A) Segregation of Villages depending on the Distance from the main Blocks

\begin{tabular}{|l|l|l|l|l|}
\hline Sl. No & Kms & Mawsynram & Pynursla & Mawrynkneng \\
\hline & $1-20$ & 42 & 59 & 15 \\
\hline & $20-50$ & 63 & 71 & 25 \\
\hline & $50-80$ & 53 & - & 18 \\
\hline & $80-110$ & - & - & 6 \\
\hline
\end{tabular}

The minimum sample sizes were selected taking $20 \%$ from the total number of Villages that fall into these various categories of distance. Table I (B) shows this division.

Table I (B) Sample Villages

\begin{tabular}{|l|c|c|c|}
\hline \multicolumn{4}{|c|}{ Sample (20\%) } \\
\hline Sl. No. & Mawsynram & Pynursla & Mawrynkneng \\
\hline 1. & 8 & 12 & 3 \\
\hline 2. & 13 & 14 & 5 \\
\hline 3. & 11 & - & 4 \\
\hline 4. & - & - & 2 \\
\hline TOTAL & 32 & 26 & 14 \\
\hline
\end{tabular}

The villages in these four categories were randomly picked determined based on the distance. The samples for the number of households chosen were based on the systematic calculation of $10 \%$ each from the total number of households available.

\section{Ethical Issues}

Approval for the study was obtained from the University Research Ethics Committee. Informed consent was taken from the community leaders and village heads of all the villages. The consent of the villagers was also taken before the interview was conducted or before the questionnaires were given to them for filling them up.

\section{Main Results}

The objective of this research is to study how educational qualification acts as a major factor for the rural masses in understanding and to be able to comprehend the messages and 
information provided by the Government through various media vehicles while seeking assistances for government schemes and grants to alleviate poverty. The educational qualifications of the respondents are segregated as follows:

Table I (C)

\begin{tabular}{|c|l|}
\hline Quote Number & Educational Qualification \\
\hline 1. & BSc / BA/ BCom/MA/MSc/MCom \\
\hline 2. & Pass Vocational Degree (ITI, Pass Computer) \\
\hline 3. & Studying below Class 12 \\
\hline 4. & Studying Below Class 8 \\
\hline
\end{tabular}

1. Responses on helped gained from the exposure to television on government schemes and grants

$63 \%$ of the respondents said that they could not understand much of what is being showed in their television sets in relation to government schemes and grants. A significant number of respondents in this category are the ones who have passed only below Class 8 and Class 12 . $14 \%$ others said that they have never gained any help from such exposure to programs on government schemes and grants.11 \% said that they are aware and updated about such exhibits, while only $10 \%$ said that they are thoroughly informed. It may be noted that in both these categories, those passing within Class 12, were the maximum respondents. Statistically, there is a significant difference in the help / guidance gained through the exposure of television on government assistance on the respondents across educational level when tested using Chi Square $(\mathrm{p}=.000)$ (Table I D).

Table I D

Watching television programs on government schemes and grants helps you in being better informed.

Crosstab

Count

\begin{tabular}{|l|l|c|c|c|c|c|}
\hline \multirow{2}{*}{\multicolumn{2}{|c|}{}} & \multicolumn{4}{c|}{ Educational Qualification } & \multirow{2}{*}{} \\
\cline { 3 - 6 } & 1 & 2 & 3 & 4 & \multirow{2}{*}{ Total (\%) } \\
\hline Watching television & GST1 & 9 & 23 & 32 & 19 & $83(10)$ \\
\hline
\end{tabular}


Volume: 7 - Issue: 3 July - 2017

\begin{tabular}{|c|c|c|c|c|c|c|}
\hline \multirow{3}{*}{$\begin{array}{l}\text { programs on government } \\
\text { schemes and grants helps } \\
\text { you in being better } \\
\text { informed. }\end{array}$} & GST2 & 8 & 23 & 41 & 24 & $96(11)$ \\
\hline & GST3 & 13 & 65 & 225 & 208 & $511(63)$ \\
\hline & GST4 & 8 & 26 & 58 & 26 & $118(14)$ \\
\hline \multicolumn{2}{|l|}{ Total } & 38 & 137 & 356 & 277 & 808 \\
\hline \multicolumn{7}{|l|}{ Chi-Square Tests } \\
\hline & \multicolumn{2}{|c|}{ Value } & \multicolumn{2}{|c|}{ Df } & \multicolumn{2}{|c|}{ Asymp. Sig. (2-sided) } \\
\hline Pearson Chi-Square & \multicolumn{2}{|c|}{$49.302^{\mathrm{a}}$} & \multicolumn{2}{|l|}{9} & \multicolumn{2}{|c|}{.000} \\
\hline Likelihood Ratio & \multicolumn{2}{|c|}{48.077} & \multicolumn{2}{|l|}{9} & \multicolumn{2}{|c|}{.000} \\
\hline $\mathrm{N}$ of Valid Cases & \multicolumn{2}{|c|}{808} & & & & \\
\hline
\end{tabular}

Note: GST1 - Am thoroughly informed; GST2 - Keeps us very aware and update; GST3 -

No, I cannot understand much of what is being shown; GST4 - Never

2. Responses on helped gained from the exposure to radio on government schemes and grants

$60 \%$ of the respondents said that they could not understand much of what is being broadcasted in their radio sets in relation to government schemes and grants. A significant number of respondents in this category are the ones who have passed only below Class 8 and Class 12. 18\% others said that they have never gained any help from such exposure to programs on government schemes and grants.12\% said that they are aware and updated about such exhibits, while only $10 \%$ said that they are thoroughly informed. It may be noted that in both these categories, those passing within Class 12, were the maximum respondents. Statistically, there is a significant difference in the help / guidance gained through the exposure of radio on government assistance on the respondents across educational level when tested using Chi Square ( $\mathrm{p}=.000)$ (Table I E).

\section{Table I E}

Listening to radio programs on government schemes and grants helps you in being better informed.

\section{Crosstab}

Count 


\begin{tabular}{|c|c|c|c|c|c|c|}
\hline & \multicolumn{4}{|c|}{ Educational Qualification } & \multirow[b]{2}{*}{ Total (\%) } \\
\hline & & 1 & 2 & 3 & 4 & \\
\hline \multirow{4}{*}{$\begin{array}{l}\text { Listening to radio programs } \\
\text { on government schemes and } \\
\text { grants helps you in being } \\
\text { better informed. }\end{array}$} & GSR1 & 7 & 18 & 27 & 16 & $68(8)$ \\
\hline & GSR2 & 11 & 18 & 50 & 24 & $103(12)$ \\
\hline & GSR3 & 9 & 70 & 211 & 199 & $489(60)$ \\
\hline & GSR4 & 11 & 31 & 68 & 38 & $148(18)$ \\
\hline \multicolumn{2}{|l|}{ Total } & 38 & 137 & 356 & 277 & 808 \\
\hline \multicolumn{7}{|l|}{ Chi-Square Tests } \\
\hline & Value & & Df & \multicolumn{3}{|c|}{ Asymp. Sig. (2-sided) } \\
\hline Pearson Chi-Square & $46.210^{\mathrm{a}}$ & & 9 & \multicolumn{3}{|c|}{.000} \\
\hline Likelihood Ratio & 45.391 & & 9 & \multicolumn{3}{|c|}{.000} \\
\hline $\mathrm{N}$ of Valid Cases & 808 & & & & & \\
\hline
\end{tabular}

Note: GSR1 - Am thoroughly informed; GSR2 - Keeps us very aware and update; GSR3 No, I cannot understand much of what is being broadcast; GSR4 - Never

\section{Responses on helped gained from the exposure to newspapers on government schemes} and grants

$60 \%$ of the respondents said that they could not understand much of what is being written in the newspapers in relation to government schemes and grants. $15 \%$ others said that they have never gained any help from such exposure to programs on government schemes and grants. A significant number of respondents in both these categories are the ones who have passed only below Class 8 and Class 12. Similarly, another $15 \%$ said that they are aware and updated about such exhibits, while only 8\% said that they are thoroughly informed. It may be noted that in both these categories, those passing within Class 12, were the maximum respondents. Statistically, there is a significant difference in the help / guidance gained through the exposure of newspaper on government assistance on the respondents across educational level when tested using Chi Square $(\mathrm{p}=.000)$ (Table I F).

\section{Table I F}

Reading newspapers on government schemes and grants helps you in being better informed. 


\begin{tabular}{|c|c|c|c|c|c|c|}
\hline \multicolumn{7}{|l|}{ Crosstab } \\
\hline \multicolumn{7}{|l|}{ Count } \\
\hline & & \multicolumn{4}{|c|}{ Educational Qualification } & \multirow[b]{2}{*}{ Total (\%) } \\
\hline & & 1 & 2 & 3 & 4 & \\
\hline \multirow{4}{*}{$\begin{array}{l}\text { Reading newspapers on } \\
\text { government schemes and } \\
\text { grants helps you in being } \\
\text { better informed. }\end{array}$} & GSN1 & 10 & 22 & 27 & 11 & $70(8)$ \\
\hline & GSN2 & 13 & 33 & 65 & 15 & $126(15)$ \\
\hline & GSN3 & 11 & 67 & 206 & 206 & $490(60)$ \\
\hline & GSN4 & 4 & 15 & 58 & 45 & $122(15)$ \\
\hline \multicolumn{2}{|l|}{ Total } & 38 & 137 & 356 & 277 & 808 \\
\hline \multicolumn{7}{|l|}{ Chi-Square Tests } \\
\hline & \multicolumn{2}{|c|}{ Value } & \multicolumn{2}{|c|}{ Df } & \multicolumn{2}{|c|}{ Asymp. Sig. (2-sided) } \\
\hline Pearson Chi-Square & \multicolumn{2}{|c|}{$85.773^{\mathrm{a}}$} & \multicolumn{2}{|l|}{9} & \multicolumn{2}{|r|}{.000} \\
\hline Likelihood Ratio & \multicolumn{2}{|c|}{85.446} & \multicolumn{2}{|l|}{9} & \multicolumn{2}{|r|}{.000} \\
\hline $\mathrm{N}$ of Valid Cases & \multicolumn{2}{|c|}{808} & & & & \\
\hline
\end{tabular}

Note: GSN1 - Am thoroughly informed; GSN2 - Keeps us very aware and update; GSN3 No, I cannot understand much of what is being written; GSN4 - Never

4. Responses On The Exposure To Newspapers By On Guidance And Counselling On Local Livelihoods / Guidance For Entrepreneurship

$82 \%$ said that exposure to newspaper on guidance and counselling on local livelihoods / guidance for entrepreneurship has not been of any help. Maximum respondents in this category are the ones who have passed below Class 8 and Class 12 and those who have pass Vocational Degree (ITI, Pass Computer). Only 6\% said that such exposure has personally helped them a lot, while $8 \%$ said that listening to such programs has vaguely given them an idea. Statistically, there is a significant difference in the help / guidance gained through the exposure from radio on guidance and counselling on local livelihoods / guidance for entrepreneurship across educational level when tested using Chi Square $(p=.000)$ (Table I G). 
Table I G

Does reading such exhibits guide you in setting up your own business or to revitalize local livelihoods through Newspaper?

\section{Crosstab}

Count

\begin{tabular}{|c|c|c|c|c|c|c|}
\hline & \multicolumn{4}{|c|}{ Educational Qualification } & \multirow[b]{2}{*}{ Total (\%) } \\
\hline & & 1 & 2 & 3 & 4 & \\
\hline \multirow{5}{*}{$\begin{array}{l}\text { Does reading such exhibits guide } \\
\text { you in setting up your own } \\
\text { business or to revitalize local } \\
\text { livelihoods Newspaper? }\end{array}$} & GCN1 & 9 & 10 & 17 & 14 & 50 (6) \\
\hline & GCN2 & 2 & 17 & 41 & 9 & 69 (8) \\
\hline & GCN3 & 3 & 2 & 9 & 3 & $17(2)$ \\
\hline & GCN4 & 0 & 2 & 1 & 1 & $4(0)$ \\
\hline & GCN5 & 24 & 106 & 288 & 250 & $668(82)$ \\
\hline \multicolumn{2}{|l|}{ Total } & 38 & 137 & 356 & 277 & 808 \\
\hline
\end{tabular}

Chi-Square Tests

\begin{tabular}{|l|c|c|c|}
\hline & Value & Df & Asymp. Sig. (2-sided) \\
\hline Pearson Chi-Square & $51.923^{\text {a }}$ & 12 & .000 \\
\hline Likelihood Ratio & 43.626 & 12 & .000 \\
\hline N of Valid Cases & 808 & & \\
\hline \multicolumn{2}{|l}{ a. 8 cells (40.0\%) have expected count less than 5. The minimum expected count is .19. } \\
\hline
\end{tabular}

Note: GCR1 - It has personally helped me a lot; GCR2 - It has vaguely given me an idea;

GCR3 - It was not very brief; GCR4 - No, I cannot understand much of what is being written; GCR5 - It has not been of any help.

\section{Responses On The Usage Of FM Radio}

79\% said that they do not listen to FM Radio. Significant respondents in this category are those who have passed below Class 8 and Class 12 . Only 20\% said that they do listen to FM Radio with majority of the respondents belonging to the educational level of Class 12 . Statistically, there is a significant difference in listening to FM Radio across educational level when tested using Chi Square $(\mathrm{p}=.000)$ (Table I H). 
Table I H

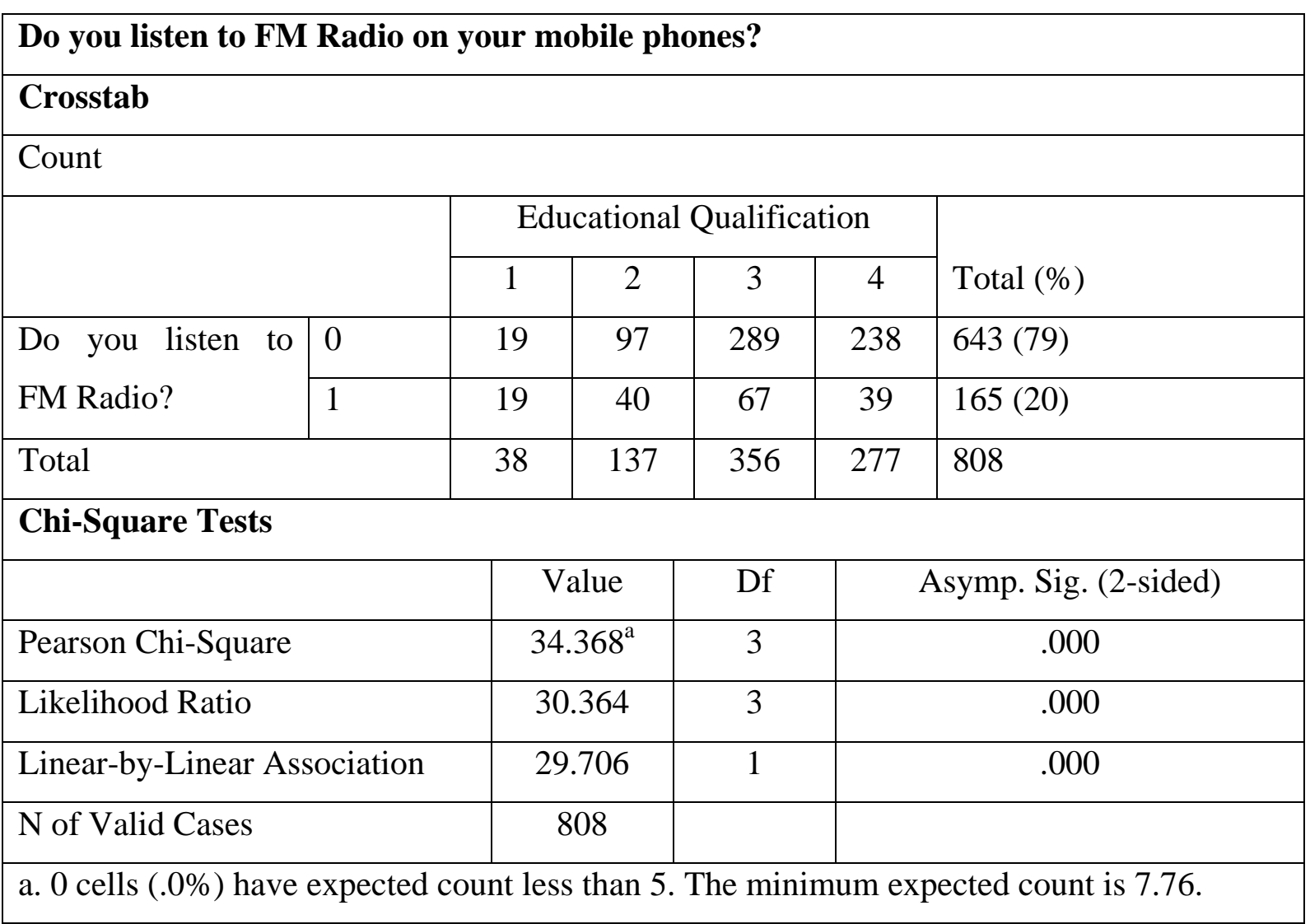

Note: $\mathbf{0}$ - No; 1 - Yes

\section{Responses on the Usage of SMS}

$83 \%$ said that they do not receive or forward messages regarding information that comes through messages on developmental activities like eradication of polio, save environment, family planning and health issues. Significant respondents in this category are those who have passed Vocational Degree (ITI, Pass Computer), passed below Class 8 and Class 12 . Only 1\% said that they do receive such SMS every day. 8\% said that they receive these SMS only sometimes while only $6 \%$ said that they do not know how to read these SMS. Statistically, there is a significant difference in receiving messages on developmental activities across educational level when tested using Chi Square ( $\mathrm{p}=.000)$ (Table I I). 
Table I I

How often do you receive or forward messages regarding information that comes through messages on developmental activities like eradication of polio, save environment, family planning and health issues?

\section{Crosstab}

Count

\begin{tabular}{|c|c|c|c|c|c|c|}
\hline & \multicolumn{4}{|c|}{ Educational Qualification } & \multirow[b]{2}{*}{ Total (\%) } \\
\hline & & 1 & 2 & 3 & 4 & \\
\hline How often do you receive or forward & IDA1 & 4 & 3 & 5 & 4 & $16(1)$ \\
\hline messages regarding information that & IDA2 & 10 & 21 & 25 & 15 & $71(8)$ \\
\hline comes through & IDA3 & 2 & 6 & 22 & 19 & $49(6)$ \\
\hline $\begin{array}{l}\text { developmental activities like } \\
\text { eradication of polio, save } \\
\text { environment, family planning and } \\
\text { health issues? }\end{array}$ & IDA4 & 22 & 107 & 304 & 239 & $672(83)$ \\
\hline Total & & 38 & 137 & 356 & 277 & 808 \\
\hline
\end{tabular}

\section{Chi-Square Tests}

\begin{tabular}{|l|c|c|c|}
\hline & Value & Df & Asymp. Sig. (2-sided) \\
\hline Pearson Chi-Square & $44.702^{\mathrm{a}}$ & 9 & .000 \\
\hline Likelihood Ratio & 32.851 & 9 & .000 \\
\hline N of Valid Cases & 808 & & \\
\hline
\end{tabular}

a. 4 cells (25.0\%) have expected count less than 5. The minimum expected count is .75 .

Note: IDA1 - Everyday; IDA2 - Sometimes; IDA3 - Don’t know how to read SMS; IDA4 -

Do not receive any such SMS

\section{Responses of the Respondents on the Causes of Poverty - Poor Quality of Schools}

$61 \%$ said that they agree that poor qualities of public schools are a major cause of poverty in our State. Majority of the respondents belong to the educational levels of those who have passed below Class 8 and Class 12. 22\% said that poor quality of public schools is just a minor cause while only $16 \%$ said that it is not a cause at all. Statistically, there is no significant difference in the opinion of the respondents on the causes of poverty in our State across educational level when tested using Chi Square $(\mathrm{p}=.477)$ (Table I J). 
Table I J

\begin{tabular}{|c|c|c|c|c|c|c|}
\hline \multicolumn{7}{|c|}{ Poor quality of schools } \\
\hline \multicolumn{7}{|l|}{ Crosstab } \\
\hline \multicolumn{7}{|l|}{ Count } \\
\hline & & \multicolumn{4}{|c|}{ Educational Qualification } & \multirow[b]{2}{*}{ Total (\%) } \\
\hline & & 1 & 2 & 3 & 4 & \\
\hline \multirow{3}{*}{$\begin{array}{l}\text { Poor quality of } \\
\text { public schools }\end{array}$} & QP1 & 25 & 82 & 222 & 168 & $497(61)$ \\
\hline & QP2 & 6 & 30 & 72 & 72 & $180(22)$ \\
\hline & QP3 & 7 & 25 & 62 & 37 & $131(16)$ \\
\hline \multicolumn{2}{|l|}{ Total } & 38 & 137 & 356 & 277 & 808 \\
\hline \multicolumn{7}{|l|}{ Chi-Square Tests } \\
\hline & & \multicolumn{2}{|l|}{ Value } & Df & \multicolumn{2}{|c|}{ Asymp. Sig. (2-sided) } \\
\hline \multicolumn{2}{|l|}{ Pearson Chi-Square } & $5.541^{\mathrm{a}}$ & \multicolumn{2}{|l|}{6} & \multicolumn{2}{|c|}{.477} \\
\hline \multicolumn{2}{|l|}{ Likelihood Ratio } & 5.618 & \multicolumn{2}{|l|}{6} & \multicolumn{2}{|c|}{.467} \\
\hline \multicolumn{2}{|l|}{$\mathrm{N}$ of Valid Cases } & \multicolumn{2}{|l|}{808} & & & \\
\hline
\end{tabular}

Note: QP1 - Major Cause; QP2 - Minor Cause; QP3 - Not a Cause at all

\section{Responses of the Respondents on the Causes of Poverty - Illiteracy}

$81 \%$ said that they agree that illiteracy is a major cause of poverty in our State. Majority of the respondents belong to the educational levels of those who have passed below Class 8 and Class 12 followed by those who have passed Pass Vocational Degree (ITI, Pass Computer). $13 \%$ said that it is just a minor cause while only $5 \%$ said that it is not a cause at all. Statistically, there is no significant difference in the opinion of the respondents on the causes of poverty in our State across educational level when tested using Chi Square $(p=.215)$ (Table I K). 
Table I K

\begin{tabular}{|c|c|c|c|c|c|c|}
\hline \multicolumn{7}{|l|}{ Illiteracy } \\
\hline \multicolumn{7}{|l|}{ Crosstab } \\
\hline \multicolumn{7}{|l|}{ Count } \\
\hline & & \multicolumn{4}{|c|}{ Educational Qualification } & \multirow[b]{2}{*}{ Total (\%) } \\
\hline & & 1 & 2 & 3 & 4 & \\
\hline \multirow[t]{3}{*}{ Illiteracy } & II1 & 35 & 112 & 293 & 216 & $656(81)$ \\
\hline & II2 & 1 & 21 & 43 & 45 & $110(13)$ \\
\hline & II3 & 2 & 4 & 20 & 16 & $42(5)$ \\
\hline \multicolumn{2}{|l|}{ Total } & 38 & 137 & 356 & 277 & 808 \\
\hline \multicolumn{7}{|c|}{ Chi-Square Tests } \\
\hline \multirow{2}{*}{\multicolumn{2}{|c|}{ Pearson Chi-Square }} & Value & \multicolumn{2}{|c|}{$\mathrm{df}$} & \multicolumn{2}{|c|}{ Asymp. Sig. (2-sided) } \\
\hline & & $8.324^{\mathrm{a}}$ & 6 & & .215 & \\
\hline \multicolumn{2}{|c|}{ Likelihood Ratio } & 10.179 & \multicolumn{2}{|l|}{6} & \multicolumn{2}{|l|}{.117} \\
\hline \multicolumn{2}{|c|}{$\mathrm{N}$ of Valid Cases } & 808 & & & & \\
\hline
\end{tabular}

Note: II1 - Major Cause; II2 - Minor Cause; II3 - Not a Cause at all

\section{Discussion}

While trying to identify the role of the media, Ghatak (n.d.) opines that if the media were to concentrate on the task of disseminating information and messages that would bring in development and improvement with regard to agriculture, health situations, upliftment of education level, it would be based on the assumption that the mass media has a very powerful, direct, and immediate effect on the listeners and the viewers as implied in the hypodermic needle theory (Katz \& Lazarsfeld, 1955).

The findings reveals that $60 \%$ of the respondents are exposed to television only sometimes on the government schemes and grants while some of them said they have never been exposed to such exhibits. This is the same scenario with radio and newspapers. While the respondents prefer viewing programmes of their likes, others are inclined to listening to songs and entertaining programmes or prefer to read on worldly events, entertaining gossips and politics etc. These preferences in using media which varies from one individual to another is perhaps 
one of the prime reasons that makes them to missed on developmental programmes provided by the Government.

While employment for youths has been placed with a lot of importance in poverty reduction programmes, job-creation strategies should have been at the top most priority at the national poverty reduction strategies. The employment strategies were often looked from the point of view of agricultural and rural development in terms of agricultural technologies, promoting micro projects in rural areas and others (Kohan, 2013). However, the findings in this research show that $85 \%$ of the respondents are of the opinion that exposure to television on guidance and counselling on local livelihoods / guidance for entrepreneurship has not been of any help to them. This was similarly expressed by respondents when it came to radio - $83 \%$ and newspapers - 82\%. The respondents have expressed that the business initiatives, resources and practice is different from one village to the other and from one geographical terrain to the other which is why they do not feel any kind of benefit from these exposures as the talks and discussions that they view, listened to or read is not relevant to what they are doing. This is perhaps why Choudhury (2011) while defining communication in the pretext of development communication elaborate that communication may be used as a means of sharing of information and experience to accelerate development.

Media therefore, has always acted as a prime tool of communication where its eventual purpose is to communicate. Communication as can be well understood is the expression of sending information or a message through different media vehicles in the form of a verbal or nonverbal message as long as an individual transmits a thought provoking idea, gesture or action, etc. But in actual communication performs more than just providing information and from one person to another and it is witnessed to have been used as an instrument to gather people together and facilitate a dialogue for them to participate in developmental activities. This kind of communication is called development communication. Rogers (1983) defined development communication as a means of using media channels to bring refers in further development. It is a concept of using the approach of communication to provide developmental messages and information to the masses to help improve their lives (as cited by Pannu \& Tomar 2010). 
When it came to programme choices in radio, 65\% said that they use to listen to other programs besides news and songs on their radio sets. In this category, most of the respondents are the ones who have passed below Class 8 and Class 12. 24\% said that they listen mostly to news with a significant number of respondents belonging to the level passing below Class 12. This showcase the variations in the listening habits of the respondents which is based on interest, educational qualification, time convenience or they like to listen to radio merely to pass their time. However, some of the respondents are regularly listening to radio to update themselves with news and events of what is happening in and around them. This data also shows that the highest educational qualifications of the respondents who are keen to listening to radio regularly are only up to Class XII which means to suggest that the in-depth comprehension of whatever developmental programmes, information and messages which are presented to the villagers reaches them half informed because they were never qualified enough to understand and utilize the same.

This is one reason why $81 \%$ of the respondents said that they agree that illiteracy is a major cause of poverty in our State Meghalaya. Majority of the respondents belong to the educational levels of those who have passed below Class 8 and Class 12 followed by those who have passed Pass Vocational Degree (ITI, Pass Computer). They have perhaps understood that illiteracy is leading them to miss on a lot of relevant information that can actually facilitate them to a better life.

In such circumstances, the poor people rely on information from their friends, family members, opinion leaders (headman, school teacher, doctor, learned of the community) and others but these informal pieces of information do not really meet their information requirements. This digital divide is a matter of great concern that can be addressed by policy makers to help increase connectivity among poor people (World Bank, 2002). Aparici and Torrent (2010) recorded that education is considered a basic human right under Article 26 of the Universal Declaration of Human Rights and as such is educommunication. Educommunication in simple words is a concept of access to information and the vast reach of disseminating information that is relevant to the receivers. Paulo Freire rightly stated that educommunication (education) is a means to a better living by which a person and the society can free itself from all the beliefs that dominate and reduce development in mankind. This would differ with the understanding of the oppressive systems who thinks that 
educommunication can actually jeopardise the moral values, political construct, economic and or other functions (Aparici \& Torrent, 2010).

In line with the above remarks, sadly $61 \%$ of the respondents opined that poor quality of public schools is a major cause of poverty in Meghalaya. Majority of the respondents belong to the educational levels of those who have passed below Class 8 and Class 12 while only $22 \%$ said that poor quality of public schools is a minor cause of poverty. This is because of the realisation that the primary and the secondary schools in the villages are not properly run and maintained which in turn leads to poor quality of education among the students in the rural villages. However, India since independence has in all efforts tried to improve the literacy rate in the country. Many literacy programmes were introduced, like the National Adult Education Programme (NAEP - 1978), Total Literacy Programmes (TLP) or National Literacy Mission (NLM - 1988) under the Five Year Plans and more recently the Saakshar Bharat which was introduced in 2009 (Abraham \& Dubey, 2013).

A simple outcome of illiteracy of the villagers is the data that shows that $82 \%$ of the respondents replied that lack of knowledge to apply for loans / grants is a major cause of poverty. Majority of the respondents belong to the educational levels of those who have passed below Class 8 and Class 12 followed by those who have passed Pass Vocational Degree (ITI, Pass Computer). This was rightly expressed by Ozowa (1995) where he mentioned that lack of awareness among the people in the villages generally contributes to a high level of illiteracy. While on the other end, the Government of India claims to have worked and allocate a lot of schemes and grants to uplift the living standards of the people. The claim is also in terms of subsidies and loans. However, the figures reflect a colossal lacuna in what is being promised and showed and the actual benefits that reaches the deserving beneficiaries at the extreme end.

$50 \%$ of the respondents said that they do not read newspapers at all. Significant respondents in this category are those who have passed below Class $8.39 \%$ others said that they do read newspapers only sometimes. While this data can be interpreted as the respondents not having interest in reading newspapers, the fact could be because they are illiterate and are not able to comprehend the content of the information given in the newspapers or the explanation given on certain schemes/grants is too technical to follow it up. 
According to Unagha \& Samuel (2011), rural area is defined as any place that lacks basic social facilities in terms of proper roads, health services, electricity, drinking water, educational institutions like schools and colleges and markets for import and export (exchange of agricultural produce). The rural dwellers consist mostly of people who are not very learned, farmers, old people and few young people because in most cases young people have migrated to the urban areas for employment. These rural masses however are not always aware of what the information that they receive necessitates and the extent to which the information users handle information will determine the effectiveness of the information as a development tool (Manzvanzvike, 1993).

However, as Boon (1992) stated, the information that the villagers received has not yet been looked at as a challenged when it is not viewed in the same light and in the same framework as other development processes. It may be reminded that information is power, but at the same time, information will become worthless if it has not been able to solve any problems. Information will only be effective if it has been thoroughly understood and applied accordingly and for this to happen, one needs to be literate enough to be able to comprehend its content.

\section{Conclusion}

The findings highlighted that the respondents do not watch, listen or read certain exhibits of the media because they do not understand the language or it is not relevant to them. These are respondents from interior most places and rural areas that were covered in the study. This finding is similar to the statistics produced by the UNESCO which shows that the penetration of newspapers, radio and television sets became alternate of development, as the message to audiences in small towns and villages in our country who have access to these sophisticated media, are lost on them because they are not area specific and lack local cultural flavours and relevance, which is very necessary for audience to identify with and understand.

It may be concluded that poverty in communication is the root cause for economic poverty. Economic poverty is a web and when caught in this vicious circle, the shortcoming of one basic facility handicaps other facilities in a person's life. The rural populace fails to understand that education is a must for people to get out of the trap of poverty. Education was 
never given due importance. One can very well assume that poverty in communication patterns have a direct impact on economic poverty and the need of the hour is to understand the impact of media channels as an effective tool to lessen communication poverty which will in turn uplift the economic lives of the rural masses in our country.

Media channels could have a far better coverage even to the most interiors of the State through proper planning and implementation. And in doing so, area identification and specification of required programmes should be part of the planning process. Language is a barrier if it is not understood by all the recipients of the message. 


\section{References}

Abraham, A. Dubey, J.P. (2013). The Road to Literacy: A Reality Check. Indian Journal of Adult Education, Vol. 74, No. 2, ISSN 0019-5006, April-June 2013

Aparici, R. Torrent, J (2010). Media and Information Literacy, Educommunication: Citizen Participation and Creativity, United Nations Educational, Scientific and Cultural Organization United Nations Alliance of Civilizations, Media Education Policy, Youth Media Magazine

Boon, J.A. (1992). Information and development: some reasons for failure. Information Society, 8 (3), 227-241.

Choudhury, Payel Sen (2011). Media in Development Communication, December 2011, Global Media Journal: Indian Edition; Dec 2011, Vol. 2 Issue 2, P1

Economic and Social Inclusion Corporation (2008-2009). What is poverty? Retrieved on June 24, 2016

http://www2.gnb.ca/content/gnb/en/departments/esic/overview/content/what_is_pover ty.html

Electronic media (n.d.) Business Dictionary.com, Retrieved on July 05, 2016 from Business Dictionary.com website http://www.businessdictionary.com/definition/\%20electronicmedia.html

Eleventh Five Year Plan (2007-2012), Social Sector Volume II, Planning Commission, Government of India, Published in India, Oxford University Press, New Delhi (C) Planning Commission (Government of India) 2008

Français E (n.d.). Communication, a key to human development, produced by: Natural Resources Management and Environment Department. FAO Corporate Document Repository, Food and Agriculture Organization of the United Nations

Ghatak, P. (n.d.) Development of Mass Media and its Extension in Agriculture: A Feedback Review of Audience Research Survey in AIR, Murshidabad, West Bengal, JRF-UGC, Dept Of Anthropology, University Of Calcutta, West Bengal, India. Retrieved on June 29, 2016 from http://www.caluniv.ac.in/global-mdia-journal/student_research-june2010/p\%20ghatak.pdf

Haloi, R (2015). Media and Rural Development International Journal of Humanities \& Social Science Studies (IJHSSS) ISSN: 2349-6959 (Online), ISSN: 2349-6711 (Print)

Volume-II, Issue-I, July 2015, Page No. 239-246 
Hazra, A (2011). The Challenge of Educating Rural India, The Monthly Journal, Ministry of Rural Development, Kurukshetra, Vol. 59 No. 7 Pages 52, May 2011. Retrieved on July 1, 2016 from http://yojana.gov.in/cms/(S(e1hdgm45zs5trp55bkv4bc45))/pdf/Kurukshetra/English/2 011/May.pdf

Human Development Report (2003), Millennium Development Goals: A compact among nations to end human poverty, Published for the United Nations Development Programme (UNDP), New York Oxford, Oxford University Press

Katz, E. Lazarsfeld, P. (1955), Personal Influence, New York: The Free Press.

Kaur, R (2013). Rural education in India, Compare Infobase Limited

New Delhi Office Retrieved on June 28, 2016 from http://www.mapsofindia.com/myindia/education/india-needs-education-especially-rural-education

Kohan, S. (2013), Poverty and employment, Harvard Law School, Weblogs at Harvard , Powered by Word Press \& designed by Scott Allan Wallick. September 4th, 2013 at 9:53 PM, Retrieved on June 29, 2016 from https://blogs.harvard.edu/kohan/povertyand-employment/

Manzvanzvike, T.H. (1993). Information access and provision in Africa: the search for an appropriate paradigm. Journal of Economic and Social Intelligence, 3 (3), 123-136.

Mathur, P (2006) Media, Technology and Rural Development. Indian Media Studies Journal Vol.1 No.1. July-Dec. 2006

Ocheni, S. Nwankwo, B.C. (2012). The Role of Mass Media in Rural Information System in Nigeria, Studies in Sociology of Science, Vol. 3, No. 3, 2012, pp. 10-14

Ozowa, V.N. (1995). Information Needs of Small Scale Farmers in Africa: The Nigerian Example. Quarterly Bulletin of the International Association of Agricultural Information Specialists, IAALD/CABI 40 (1).

Pannu, P. Tomar, Y, A. (2010), ICT4D Information Communication Technology for Development, Edition illustrated, Publisher I. K. International Pvt Ltd Poverty Eradication / Alleviation In North East India: An Approach (N.D.) Sponsored by the North Eastern Council, Shillong, Prepared By: National Institute of Rural Development (NIRD) North Eastern Regional Center (NERC), Guwahati Poverty. (n.d.). Dictionary.com Unabridged. Retrieved on July 04, 2016 from Dictionary.com website http://www.dictionary.com/browse/poverty 
Print media (n.d.) Business Dictionary.com, Retrieved on July 05, 2016 from Business Dictionary.com website http://www.businessdictionary.com/definition/electronicmedia.html

Right to Education, The Monthly Journal, Ministry of Rural Development, Kurukshetra, Vol. 59 No. 7 Pages 52, May 2011. Retrieved on June 30, 2016 from http://yojana.gov.in/cms/(S(e1hdgm45zs5trp55bkv4bc45))/pdf/Kurukshetra/English/2 011/May.pdf

Sambhaji, P, A (2014). Impact of the Media in Rural Development India International Journal of Management and Commerce Innovations ISSN 2348-7585 (Online) Vol. 2, Issue 2, pp: (339-340)

Telecommunications and Information Services for the Poor, Towards a Strategy for Universal Access (2002). The World Bank, World Bank Discussion Paper No.432

The Challenges of Education in Rural India (2013) Posted by Foradian — Dec 31, 2013. Retrieved on June 30, 2016 from http://www.foradian.com/the-challenges-ofeducation-in-rural-india

Unagha, A. O. I, Samuel K., "Obstacles to Provision and Use of Development Information in Rural Communities in Nigeria" (2011). Library Philosophy and Practice (e-journal). Paper 511. http://digitalcommons.unl.edu/cgi/viewcontent.cgi?article=1529\&context=libphilprac University of Twente (n.d.). Hypodermic Needle Theory, Retrieved on June 23, 2016 from https://www.utwente.nl/cw/theorieenoverzicht/Theory\%20Clusters/Mass\%20Media/H ypodermic_Needle_Theory/ 